\title{
New Insights into the Neuropathogenesis of Molybdenum Cofactor Deficiency
}

\author{
Michael S. Salman, Cameron Ackerley, Christof Senger, Laurence Becker
}

\begin{abstract}
Background: Molybdenum cofactor deficiency (MOCOD) is a rare, progressive neurodegenerative disorder caused by sulphite oxidase enzyme deficiency. The neuropathological findings are consistent with a toxic insult to the brain that causes severe neuronal loss, reactive astrogliosis and spongiosis. The mechanisms responsible for these changes are unknown. Methods: The case is a male infant with MOCOD who died at nine months of age from pneumonia. At autopsy, a complete neuropathological examination was performed including conventional immunohistochemical staining. In addition, brain sections were stained cytochemically with shikata and orcein which stain for disulphide bonds. The elemental composition of cortical cells was then analyzed in the scanning electron microscope using backscatter electron imaging and energy dispersive X-ray spectrometry. Results: Neurons demonstrated cytoplasmic staining with shikata and orcein cytochemically when compared to control sections. Energy dispersive X-ray spectrometry analysis of these neurons confirmed the presence of excess sulphur and unexpectedly revealed excess magnesium accumulation. None of these findings was found in an age-matched control. Conclusions: In MOCOD we found abnormal accumulation of sulphur and magnesium in neurons. It is postulated that sulphur-containing compound(s) that are formed as a result of MOCOD cause excitotoxic neuronal injury in the presence of excess magnesium.
\end{abstract}

RÉSUMÉ: Nouveaux concepts dans la neuropathogenèse de la déficience en cofacteur à molybdène. Introduction: La déficience en cofacteur à molybdène (DCOMO) est une maladie neurodégénérative progressive rare causée par une déficience en sulphite oxydase. Les observations neuropathologiques sont compatibles avec une lésion toxique du cerveau qui cause une perte neuronale sévère, une astrogliose et une spongiose réactionnelles. Les mécanismes responsables de ces changements sont inconnus. Observation: Il s'agit d'un enfant mâle atteint de DCOMO qui est décédé à l'âge de neuf mois de pneumonie. À l'autopsie, un examen neuropathologique complet a été effectué, ainsi que des études conventionnelles de coloration immunohistochimiques et des colorations cytochimiques au shikata et à l'orcéine qui colorent les ponts disulphures. La composition élémentaire des cellules corticales a ensuite été analysée au microscope électronique à balayage utilisant la scintigraphie électronique radiodiffusée et la spectrométrie de rayons X induits par particules chargées. Résultats: Contrairement aux sections contrôles, les neurones présentaient une coloration cytoplasmique au shikata et à l'orcéine. L'analyse spectrométrique de ces neurones a confirmé la présence d'un excès de soufre et a montré la présence insoupçonnée d'un excès de magnésium. Aucune de ces observations n'a été retrouvée chez des contrôles appariés pour l'âge. Conclusions: Dans le DCOMO, nous avons observé une accumulation anormale de soufre et de magnésium dans les neurones. Nous postulons que le(s) composé(s) soufré(s) qui sont formés dans la DCOMO causent une lésion neuronale excitotoxique en présence d'un excès de magnésium.

Can. J. Neurol. Sci. 2002; 29: 91-96

Molybdenum is found in most foods including legumes, dairy products and meats. It is an important element that forms a complex called molybdenum cofactor. Three mammalian enzymes depend on this cofactor for their function. These enzymes are (i) sulphite oxidase, a terminal enzyme, essential for detoxifying sulphites; (ii) xanthine dehydrogenase, which plays a role in purines metabolism and the formation of uric acid from xanthine and hypoxanthine and (iii) aldehyde dehydrogenase, which catalyses the conversion of aldehydes to acids. ${ }^{1}$

Molybdenum cofactor deficiency (MOCOD, OMIM\# 252150) is a rare, autosomal recessive, neurodegenerative metabolic disorder that affects the central nervous system through sulphite oxidase deficiency. ${ }^{2}$ Clinically, the disease causes progressive cerebral degeneration, severe seizures, spasticity, lens dislocation, and developmental delay. ${ }^{1}$

From the Departments of Neurology (MSS), Laboratory Medicine and Pathobiology

(CA, CS, LB) Hospital for Sick Children, Toronto, ON, Department of Pediatrics,

University of Toronto, Toronto, ON, (LB), Canada.

RECEIVED APRIL 30, 2001. ACCEPTED IN FINAL FORM August 8, 2001.

Reprint requests to: Michael S. Salman, Division of Neurology, Hospital for Sick Children, 555 University Avenue, Toronto, ON, M5G 1X8, Canada 
Little is known about the pathogenesis of this disease, which is thought to be caused by sulphite oxidase deficiency rather than xanthine or aldehyde dehydrogenase deficiency. ${ }^{1,3}$ Some authors have speculated that it is most likely to be caused by sulphite toxicity or sulphate deficiency. ${ }^{1,2,3}$ A phenotype resembling MOCOD has been produced in mice by targeting the gene for the cytoplasmic protein, gephyrin. ${ }^{4}$ Gephyrin is required in anchoring glycine receptors at inhibitory chemical synapsis and molybdonum cofactor biosynthesis in mice. Its role in MOCOD in humans is yet to be determined.

There are only few case reports describing the neuropathological findings of MOCOD in humans, ${ }^{1,5,6,7}$ with no reports on the sulphur content within the brain cells.

In this study, attempts were made to further elucidate the neuropathogenesis of MOCOD by examining brain tissue sections taken from an autopsy of a patient with this disorder. The sulphur content and its distribution in the central nervous system was studied using a variety of cytochemical stains and energy dispersive x-ray spectrometry (EDS).

The latter method was employed because it does not cause the translocation of elements from cells thus permitting the microanalysis of a number of elements (i.e. sodium, magnesium, sulphur, chlorine, potassium and calcium) in the nucleus and cytoplasm of individual cells within the brain. ${ }^{8}$

\section{Clinical history}

This male infant was the second child of unrelated Afghanistani parents. The pregnancy and delivery were unremarkable. APGAR scores were 7 at one minute and 9 at five minutes. Birth weight was $3.97 \mathrm{~kg}$. On the first day of life, he developed respiratory distress and seizures. $\mathrm{He}$ was mechanically ventilated for two days and treated with phenobarbital. Very low plasma urate $(<30 \mu \mathrm{mol} / \mathrm{L})$ and elevated urinary S-sulphocysteine confirmed the diagnosis of MOCOD. Blood homocystine was not detected and peak serum lactate was $4.47 \mathrm{mmol} / \mathrm{L}$. The insertion of a gastrostomy feeding tube on day 10 of life was complicated by peritonitis and intra-abdominal abscess. Over the following few months, his clinical condition worsened progressively with evidence of spastic quadraparesis, intractable seizures, poor vision, right lens subluxation, severe developmental delay, and microcephaly. He died unexpectedly at nine months of age, of sepsis caused by Staphylococcus aureus and complicated by acute early pneumonia, which were demonstrated during post mortem autopsy examination.

\section{MATERIALS AND METHODS}

Multiple sections of brain were stained with haematoxylin and eosin stain. Additional sections from areas in the temporal lobes that were not extensively destroyed by the disease were selected and stained with shikata and orcein. These stains are used routinely to detect the presence of hepatitis B surface antigen and copper binding protein on liver biopsies. The mechanism of staining is related to the presence of disulphide ( $\mathrm{S}$ S) bonds. ${ }^{9,10}$ We have used these stains on brain specimen at our institution. We did not find any published report in the literature on their use in brain sections hence an age-matched control case was used in our study.

Standard immunohistochemical procedures on sections in the same cortical brain regions using synaptophysin (monoclonal antibody, clone SY 38, 1:5 dilution, Roche Diagnostics,
Mannheim, Germany), and neurofilaments (monoclonal antibody, clone 2f11, 1:400 dilution, Sanbio, Uden, Netherlands) were performed on the Ventan Gen II $^{\mathrm{TM}}$ auto-immune/in-situ stainer (Ventana Medical Systems, Tucson, Arizona, USA) with a closed ABC system employing DAB (3-3' Diaminobenzidine) Ventana Detection System (Cat \# 250-001) as the chromagen substrate. Antibodies against glial fibrillary acidic protein (GFAP) (polyclonal antibody, 1:1000 dilution, Dako, Carpinteria, Ca, USA) were performed manually using the Vector Elite ABC detection system (Vector Laboratories, Burlingame, Ca, USA). All tissue sections were treated with endogenous peroxidase.

Temporal lobe tissue sections were mounted on carbon planchete, dewaxed, and then examined in a JEOL JSM 820 scanning electron microscope using backscatter electron imaging, initially at low magnification to identify neurons and astrocytes. Areas with a relatively higher contrast were then selected and analyzed with a static electron probe using $\operatorname{EDS}^{11}$ at higher magnification. Although electron microscopy was used to examine the mitochondria, these organelles were not preserved well enough to comment further on their structure. The findings were compared to control specimens of brain sections from an 8.3 months old infant.

\section{RESULTS}

Examination of the brain showed atrophy with brain weight reduced to $342 \mathrm{~g}$ compared to a normal mean for age of $820 \mathrm{~g}$ $(\mathrm{SD} \pm 49 \mathrm{~g}) .^{12}$ On removal of the brain, cystic dilatation of the subarachnoid space was identified in the longitudinal fissure between the frontal lobes, in the right temporal area, and along the posterior fossa midline. There was $1 \mathrm{~cm}$ rostral displacement of the pons and cerebellum through the tentorium cerebelli incisura. The tentorium cerebelli was hypoplastic. The posterior fossa was normal in size. The cerebral hemispheres were

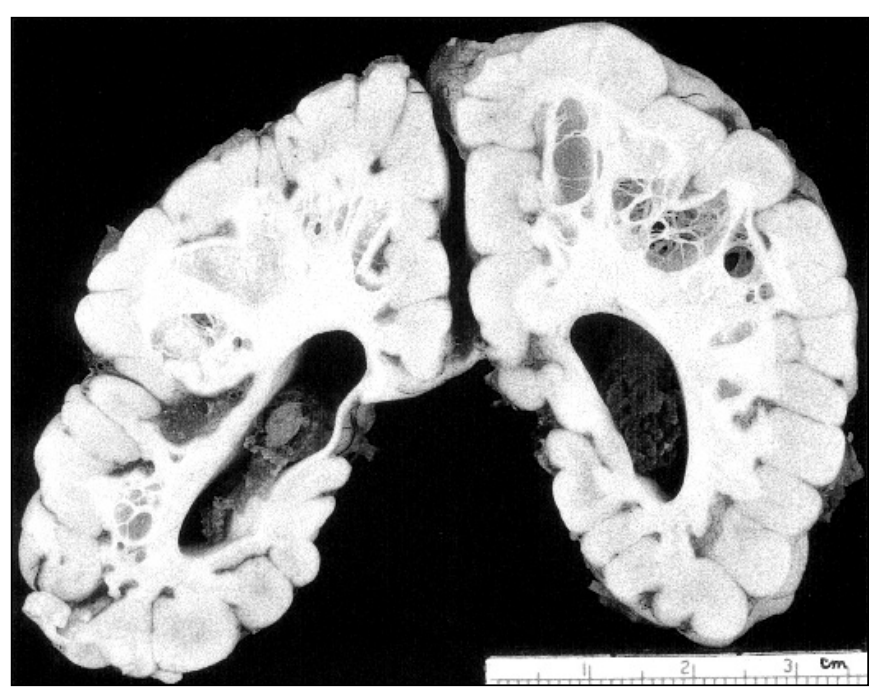

Figure 1 (i): Gross coronal section of the cerebral hemispheres showing prominent honeycombing of the white matter with cysts of varying size separated by thin strands of residual tissue. The cortical gyri are atrophic with widening of the sulci and narrowing of gyri. The ventricular system is enlarged. 


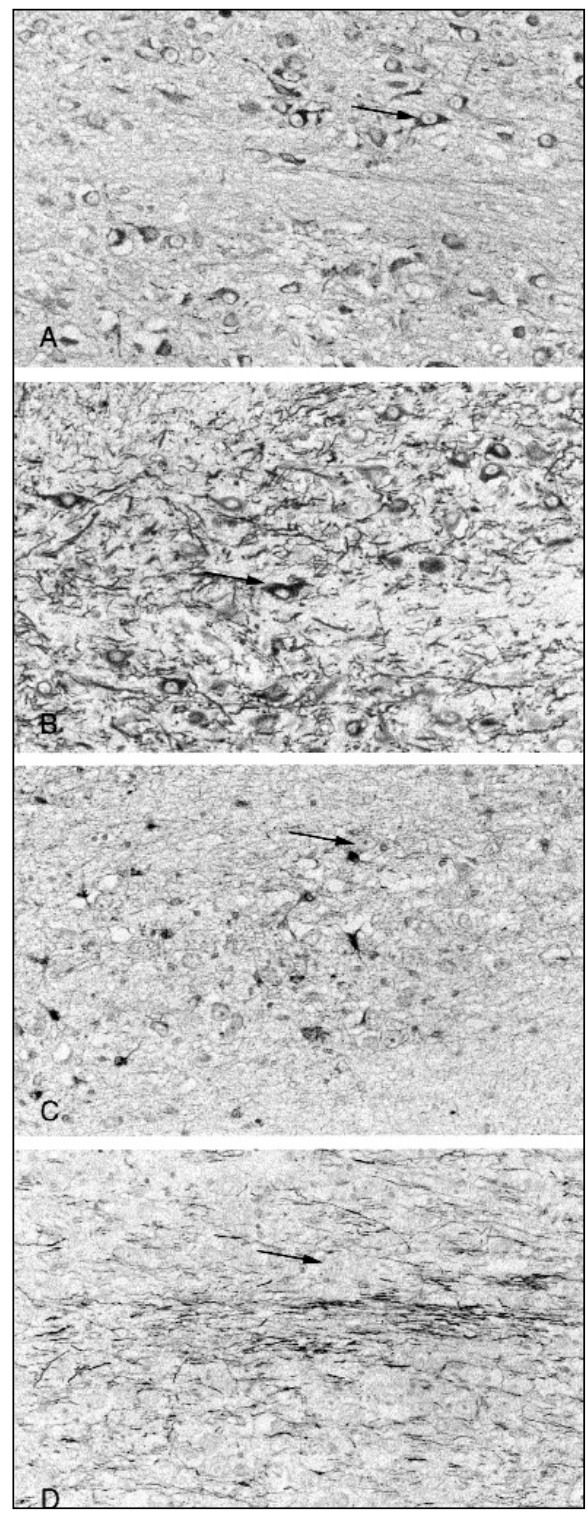

Figure 1 (ii): Illustrations A through D are light microscopy sections from the temporal cortex stained with shikata (A), synaptophysin (B), glial fibrillary acidic protein $(G F A P)(C)$, and neurofilaments $(D)$. They are all taken at $X 400$ magnification from the same site. Arrows in the pictures show representative neurons. Illustration A shows selective accumulation of shikata stain in the cytoplasm of cell bodies that stained positively with the neuronal stainsynaptophysin (illustration B) and negatively with the astrocyte stain-GFAP (illustration $C$ ). Illustration D shows axons, another cell subcompartment not showing accumulation of shikata stain. Comparable sections from an agematched male infant, did not show shikata accumulation in any of the cells.

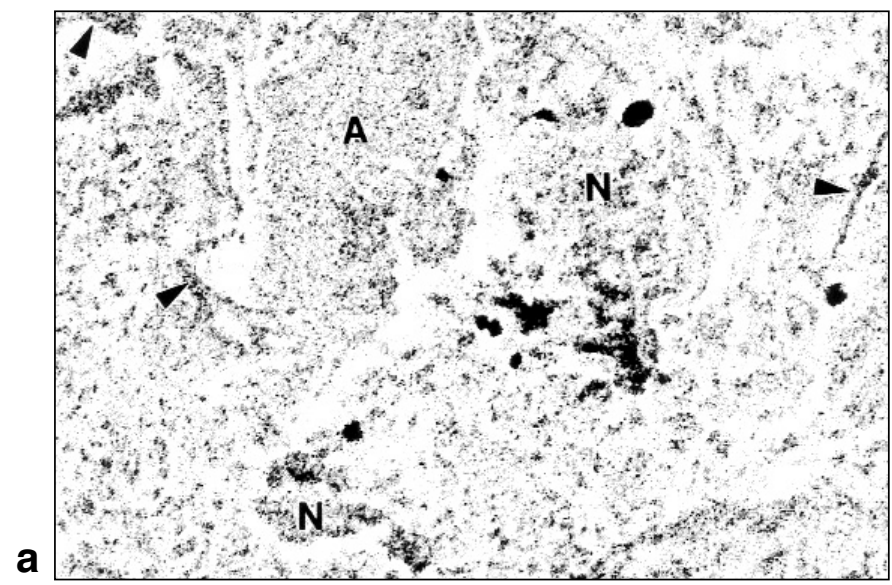

Figure 2a: The scanning electron microscope backscatter electron image from of several brain cells. An astrocyte $(A)$ is seen adjacent to a neuron $(N)$. Dendritic processes are evident (arrowheads). The cells' identity is based on their appearance at lower power magnification.
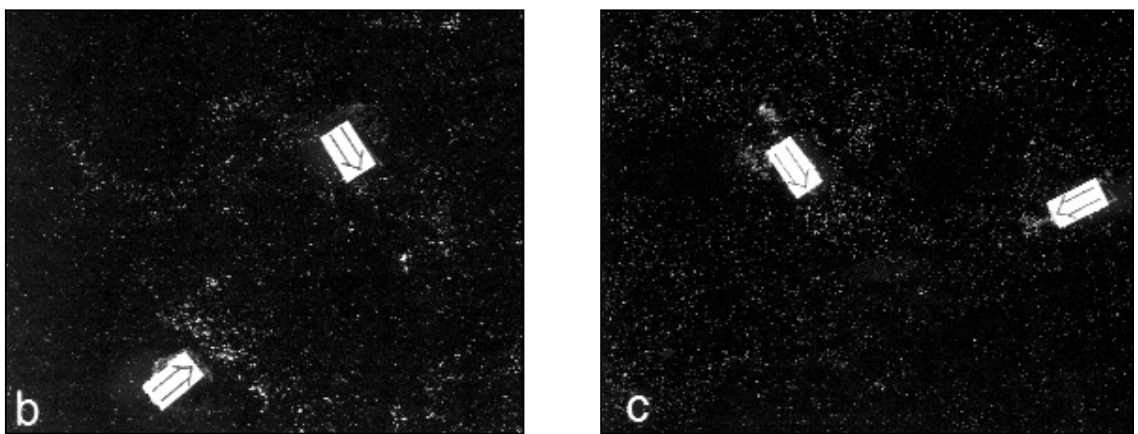

Figure 2b: X-ray map of image (2a) showing sulphur distribution, high concentration of sulphur was found in the neuronal cell body and dendritic processes (open arrows).

Figure 2c: X-ray map of image (2a) showing magnesium distribution, high magnesium concentration was found primarily in the neuronal cell body (open arrows).

Width in all photographs is 250 um.

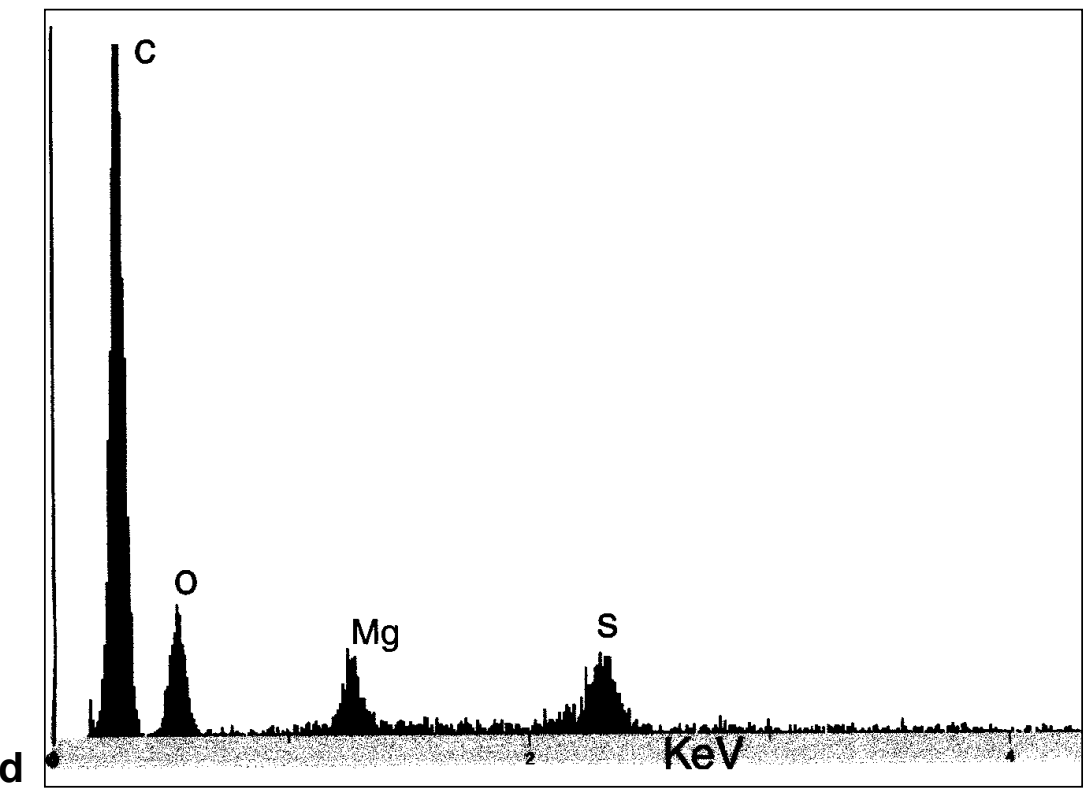

Figure 2d: X-ray energy microanalysis of a neuron demonstrating abnormal presence of sulphur $(S)$ and magnesium $(\mathrm{Mg})$ in addition to carbon $(\mathrm{C})$ and oxygen $(\mathrm{O})$ that are normally present. The $x$-axis shows the $x$-ray energy in $\mathrm{KeV}$, the $y$-axis shows $x$-ray counts. 
symmetrical. Coronal slides of the cerebral hemispheres (Figure 1-(i)) showed prominent honeycombing of the white matter with what appeared to be relatively well-preserved cortex. The cystic changes in the centrum ovale were diffusely and symmetrically distributed. There were cysts of varying size separated by thin strands of residual tissue. The cortical gyri were atrophic causing secondary widening of the sulci. The ventricular system was dilated. The deep gray nuclei of the cerebral hemispheres, the optic nerves and tracts, and the cerebellum, brain stem and spinal cord appeared grossly normal.

Microscopic examination showed extensive changes in the cerebral gray and white matter. In all areas of the cortex there was extensive neuronal loss and astrogliosis. The centrum semiovale showed extensive cystic change bilaterally with only a sparse residua of myelinated axons and extensive astrogliosis in the background. In the basal ganglia, thalamus and brain stem there was focal neuronal loss and astrogliosis. The spinal cord showed bilateral symmetrical early Wallarian degeneration of the cortico-spinal tracts.

Schikata and orcein stains showed excessive cytoplasmic staining in some cortical cells. These cells were synaptophysin positive and GFAP negative thus confirming their identity as neurons. Neurofilament immunohistochemistry was used to highlight axons, which did not show excessive accumulation of shikata or orcein (Figure 1-(ii)). Backscatter electron imaging of the abnormal areas showed an increase in contrast within neurons reflecting the presence of elements with a relatively higher atomic number (higher $\mathrm{z}$-contrast). X-ray energy microanalysis of these areas revealed abnormal energy peaks that corresponded to the presence of excessive amounts of sulphur in the neuronal cell body and dendrites and, also, excessive amounts of magnesium in the neuronal cell body (Figure 2).

Specimens from the control did not show abnormal staining with shikata and orcein stains nor was any sulphur or magnesium found in any of the neurons using EDS.

\section{Discussion}

The neuropathological findings described above resemble those in previous reports of the abnormalities associated with MOCOD. ${ }^{5,6,7}$ The changes are characterized by severe neuronal loss with widespread astrogliosis in the cortex, and extensive cystic changes involving the white matter causing significant cortical atrophy. Widening of the sulci, loss of brain volume, and cystic changes in the white matter have also been reported in neuroimaging studies in patients with MOCOD. ${ }^{13,14}$

Our report also demonstrates excessive neuronal accumulation of sulphur and magnesium in the neurons of a patient with MOCOD, compared with an age-matched control. Energy dispersive $\mathrm{x}$-ray spectrometry has not shown excessive accumulation of sulphur or magnesium in resected brain cortices in patients with Sturge-Weber syndrome,$^{15}$ indicating that our finding is unlikely to be a non-specific response to excitotoxic neuronal cell injury caused by the ischaemia or seizures that occur in patients with Sturge-Weber syndrome.

Many studies have speculated on the role of sulphite toxicity or sulphate deficiency in the pathogenesis of MOCD (Figure 3). ${ }^{1,3}$ Sulphatides are organic sulphate esters present in myelin and dependent on the availability of organic sulphate for their synthesis. In one study ${ }^{16}$ of a patient with sulphite oxidase

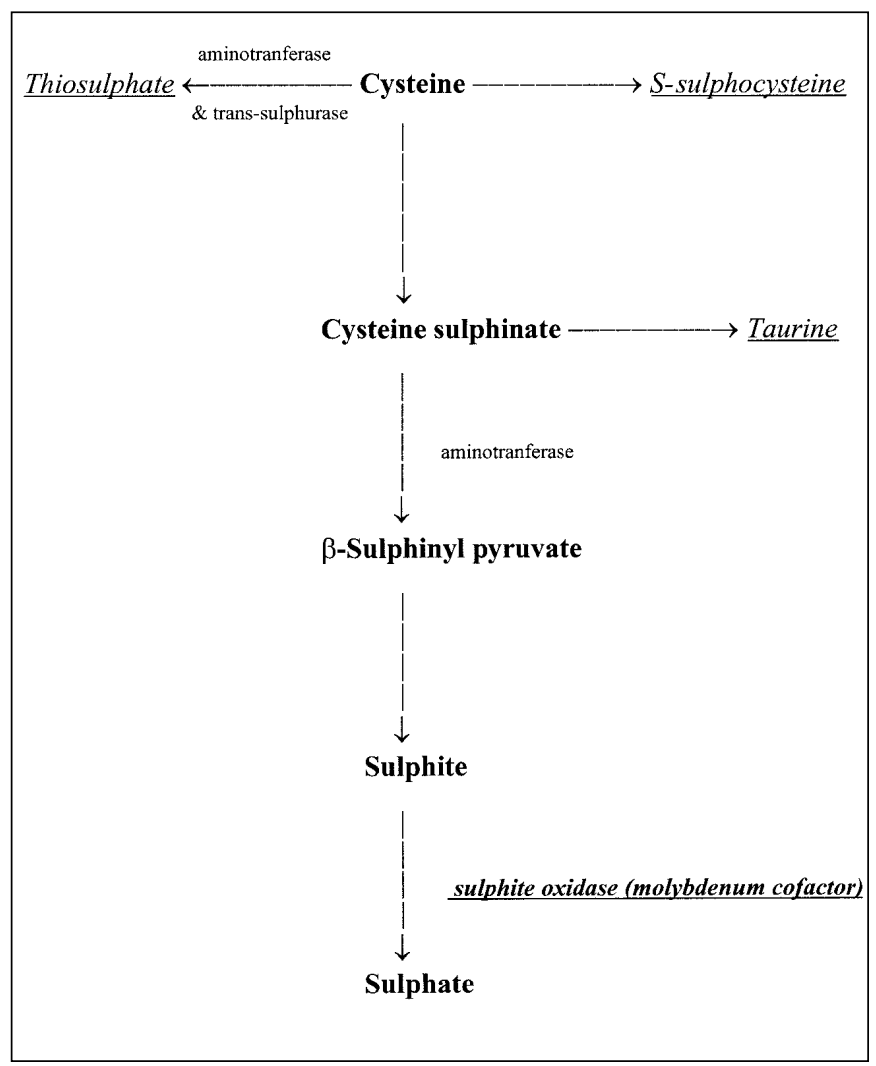

Figure 3: Cysteine metabolism pathway.

Sulphates are formed from cysteine in a multi-step biochemical reaction (highlighted in bold). The last step involves the enzyme sulphite oxidase and its molybdenum cofactor. This enzyme converts sulphites into sulphates. Excess sulphites accumulate when molybdenum cofactor and/ or sulphite oxidase enzyme are deficient. This results in the excessive synthesis of taurine, thiosulphate and S-sulphocysteine (underlined in italics).

deficiency, it was found that the anticipated sulphate deficiency did not cause a qualitative or quantitative deficiency of sulphatides. In addition, a patient with MOCOD demonstrated normal excretion of sulphates in the urine. ${ }^{1}$ Hence sulphate deficiency is unlikely to account for the pathogenesis of this disease. In contrast, a number of mechanisms are implicated in the evolution of this disease. Sulphites and sulphite radicals are toxic to neurons, attacking disulphide bonds and damaging nucleic acids. ${ }^{17}$ They also react with proteins and unsaturated fatty acids possibly compromising the cell membrane., ${ }^{1,17}$ Sulphite oxidase resides within the intermembrane space of the mitochondria. ${ }^{1}$ Excess sulphite containing compound(s) may impair mitochondrial function, ${ }^{3}$ directly via disruption of membrane integrity or indirectly by interfering with thiamine in the tricarboxylic acid cycle. ${ }^{1}$ Mitochondrial structural damage could not be assessed in this study due to post mortem artifacts.

The techniques used in this study cannot identify the compound(s) containing the excess sulphur. A likely candidate is S-sulphonated-L-cysteine (Figure 3), formed as a result of the sulphite reaction with protein cysteine and cysteine residues. The molecular structure of this compound closely resembles 
glutamate. S-sulphonated-L-cysteine injection causes neuropathological damage that extended well beyond the injecting site, a pattern of damage similar to that induced by glutamate. ${ }^{18}$ Also, sulphur-containing amino acids (including S-sulphonatedL-cysteine, cysteine sulphinate, cysteic acid) cause an increase in intracellular cyclic guanosine monophosphate (cGMP) and calcium concentrations, and are toxic to cultured cerebral cortical neurons. ${ }^{19}$ This neuronal cytotoxicity and elevation in intracellular cGMP concentrations were blocked by N-methyl Daspartate (NMDA) receptor antagonists, suggesting that sulphonated amino acid neuronal cytotoxicity is mediated by NMDA receptors. Cysteine sulphinate also has glutamate-like properties and may be involved in the development of delayed neuronal death in the rat hippocampus neurons. ${ }^{20}$ Other products of detoxification resulting from molybdenum cofactor deficiency include thiosulphate and taurine, the latter is an inhibitory neurotransmitter produced from cysteine sulphinate (Figure 3).

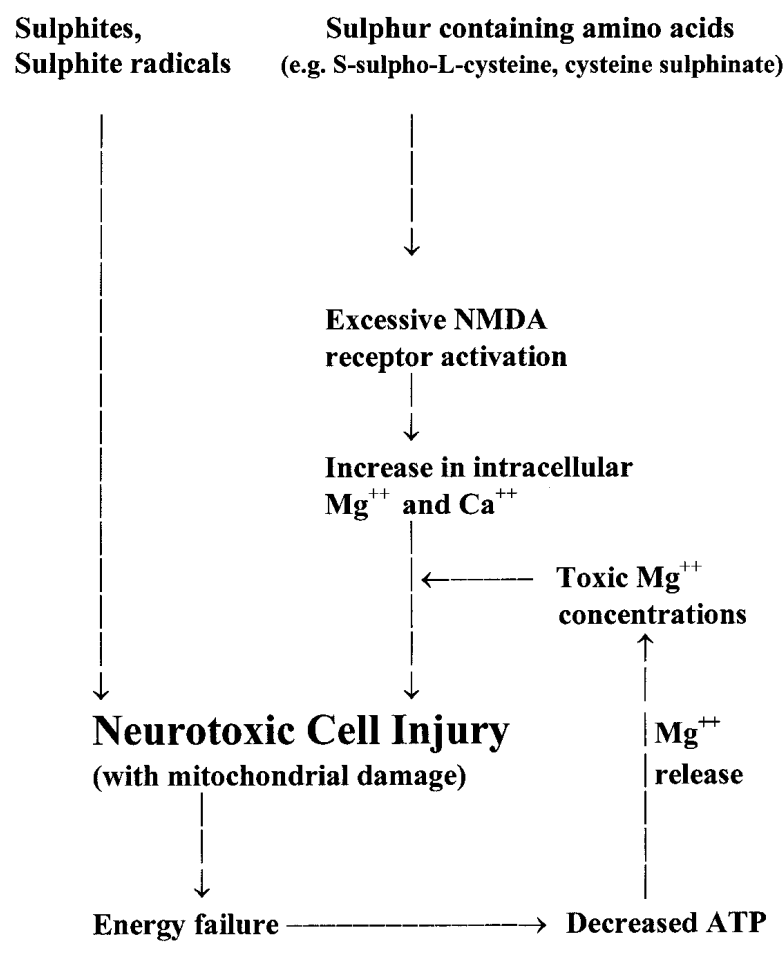

Figure 4: Hypothetical mechanism for neuronal injury in MOCOD. Molybdenum cofactor or sulphite oxidase deficiency produces excess sulphites. This can cause neuotoxicity via multiple mechanisms. First, sulphites can cause cellular disruption and damage when they react with lipids and proteins. Second, sulphites can also form radicals that damage nucleic acids and attack disulphide bonds. Third, sulphites may disrupt the mitochondrial membrane integrity or interfere with the tricarboxylic acid cycle, causing ATP loss and release of magnesium. Fourth, excessive production of sulphur-containing amino acids (e.g. Ssulphocysteine), glutamate-like compounds that may cause excessive activation of the NMDA receptor, resulting in an increase in intracellular calcium and magnesium with consequent excitotoxic neuronal damage. The presence of toxic magnesium concentrations may exacerbate NMDA induced excitotoxic damage.
These products' role in the pathogenesis of this disease is unknown and requires further evaluation.

The finding of excessive magnesium was unexpected. Magnesium is present in many types of cells including neurons and is the second most abundant intracellular cation, after potassium. It is an important cofactor in most adenosine triphosphate (ATP)-mediated reactions, such as oxidative phosphorylation, protein synthesis, nucleic acid synthesis, carbohydrate metabolism, and lipid metabolism, ${ }^{21}$ and plays a critical role within the excitatory glutamate NMDA receptor complex.

$\mathrm{N}$-methyl D-aspartate receptor activation of cultured rat cortical neurons caused an increase in intracellular magnesium concentration which correlated with neurotoxicity when it was present in excess, suggesting a role for magnesium in excitotoxic injury and delayed neuronal death. ${ }^{22}$ This mechanism may potentiate NMDA-mediated cellular excitotoxicity as ATP is a strong magnesium chelator. ${ }^{23}$ Therefore, a drop in ATP concentration following cell injury is likely to result in the release of cellular magnesium. Based on these findings, a hypothetical and simplified mechanism for neuronal death in MOCOD is proposed (Figure 4).

Further studies are required to duplicate our findings in patients with MOCOD, and other patients with excitotoxic neuronal injury e.g. seizures or ischaemia. The next step will be to identify the sulphur and magnesium-containing compound(s) that accumulate in affected neurons.

\section{ACKNOWLEDGEMENT}

We thank Dr. M.A. Cortez for his valuable comments on the manuscript, Yew Meng Heng, Michael Ho, Jimmy Choi, and Mike Starr for their technical help, and Dr. A. Feigenbaum who diagnosed and looked after the patient.

\section{REFERRENCES}

1. Johnson JL, Wadman SK. Molybdenum cofactor deficiency and isolated sulphite oxidase deficiency. In: Scriver CR, Beaudet AL, Sly WS, Valle D, eds. The Metabolic Basis of Inherited Disease, 7th Ed. New York: McGraw-Hill, 1995: 2271-2283.

2. Sardesai VM. Molybdenum: an essential trace element. Nutr Clin Prac 1993; 8: 277-281.

3. Hughes EF, Fairbanks L, Simmonds HA, Robinson RO. Molybdenum cofactor deficiency - phenotypic variability in a family with a late-onset variant. Dev Med Child Neurol 1998; 40: 57-61.

4. Feng G, Tintrup H, Kirsh J, et al. Dual requirement for gephyrin in glycine receptor clustering and molybdoenzyme activity. Science 1998; 282:1321-1324.

5. Barth PG, Beemer FA, Cats BP, Duran M. Neuropathological findings in a case of combined deficiency of sulphite oxidase and xanthine dehydrogenase. Virchows Arch (Pathol Anat) 1985; 408: 105-106.

6. Roth A, Nogues C, Monnet JP, Ogier H, Saudubray JM. Anatomopathological findings in a case of combined deficiency of sulphite oxidase and xanthine oxidase with a defect of molybdenum cofactor. Virchows Archiv (Pathol Anat) 1985; 405: 379-386.

7. Rosemblum WI. Neuropathologic changes in a case of sulphite oxidase deficiency. Neurology 1968; 18: 1187-1196.

8. Cameron IL, Sheridan PJ, Smith NR. An x-ray microanalysis study of differences in concentration of elements in brain cells due to opiates, cell type, and subcellular location. J Neurosci Res 1978; 3: 397-410.

9. Shikata T, Uzawa T, Yoshiwara N, Akatsuka T, Yamazaki S. Staining methods for Australia antigen in paraffin section - 
detection of cytoplasm inclusion. Jap J Exp Med 1974;44:25-36.

10. Deodhar KP, Tapp E, Scheuer P. Orcein staining of hepatitis B antigen in paraffin sections of liver biopsies. J Clin Path 1975;28(1):66-70.

11. Ingram P, Shelbourne JD, Roggli VL. Microprobe Analysis in Medicine. Hemisphere Publishers, Washington, DC, 1989.

12. Schulz DM, Giordano DA, Schulz DH. Weights of organs of fetuses and infants. Arch Pathol 1962;74:244.

13. Appignani BA, Kaye EM, Wolpert SM. CT and MRI appearance of the brain in two children with molybdenum cofactor deficiency. AJNR Am J Neurol Radiol 1996; 17:317-320.

14. Salvan A, Chabrol B, Lamoureux S, et al. In vivo brain proton MR spectroscopy in a case of molybdenum cofactor deficiency. Pediatr Radiol 1999;29:846-848.

15. Provias J, Ackerley CA, Jay V, Becker LE. Pathogenesis of mineralization in Sturge-Weber syndrome: analysis of resected cortex, utilizing light microscopy, stem, and X-ray microprobe analysis. Can J Neurol Sci 1993;20:84.

16. Percy AK, Mudd SH, Irreverre F, Laster L. Sulphite oxidase deficiency: sulfate esters in tissues and urine. Biochem Med 1968;2:198-208

17. Reist M, Marshall K, Jenner P, Halliwell B. Toxic effects of sulphite in combination with peroxynitrite on neuronal cells. J Neurochem 1998; 71:2431-2438.
18. Olney JW, Misra $\mathrm{CH}$, Gubareff T. Cysteine-S-sulphate: brain damaging metabolite in sulphite oxidase deficiency. J Neuropathol Exp Neurol 1975;34:167-177.

19. Frandsen A, Schousboe A, Griffiths R. Cytotoxic actions and effects on intracellular calcium and cGMP concentrations of sulphurcontaining excitatory amino acids in cultured cerebral cortical neurons. J Neurosci Res 1993;34(3):331-339.

20. Andine P, Orwar O, Jacobson I, Sandburg M, Hagberg H. Extracellular acidic sulphur-containing amino acids and gammaglutamyl peptides in global ischemia: postischemic recovery of neuronal activity is paralleled by a tetrodotoxin-sensitive increase in cysteine sulfinate in the CA1 of the rat hippocampus. J Neurochem 1991;57(1):230-236.

21. Anderson KA, Talcott PA. Magnesium. In: Seiler HG, Sigel A, Sigel $\mathrm{H}$, eds. Handbook on metals in clinical and analytical chemistry. New York, Basel, Hong Kong: Marcel Dekker, 1994;453-466.

22. Hartnett KA, Stout AK, Rajdev S, et al. NMDA receptor-mediated neurotoxicity: a paradoxical requirement for extracellular magnesium in sodium and calcium-free solutions in rat cortical neurons in vitro. J Neurochem 1997;68(5):1836-1845.

23. Gitzelmann R, Steinmann B, Van den Berghe G. Chapter 23. In: Scriver CR, Beaudet AL, Sly WS, Valle D, eds. The Metabolic Basis of Inherited Disease, 7th Ed. New York: McGraw-Hill, 1995: 912 